\title{
The Aluminum Based Composite Produced by Self Propagating High Temperature Synthesis
}

\author{
Agus PRAMONO ${ }^{1,2}{ }^{*}$, Lembit KOMMEL ${ }^{1}$, Lauri KOLLO ${ }^{1}$, Renno VEINTHAL ${ }^{1}$ \\ ${ }^{1}$ Department Material Engineering, Tallinn University of Technology, Ehitajate tee 5, 19086 Tallinn Estonia \\ ${ }^{2}$ Department Metallurgy, University of Sultan Ageng Tirtayasa, Jl. Jend Sudirman Km.03 Banten Indonesia \\ cross $^{\text {ref }}$ http://dx.doi.org/10.5755/j01.ms.22.1.7500
}

Received 01 July 2014; accepted 20 March 2015

\begin{abstract}
Self-propagating high-temperature synthesis method can be used for producing aluminum and boron carbide based composites. The experimental composites were fabricated using cobalt and carbon as catalysts. The microstructure of the material was studied using Scanning Electron Microscopy and the mechanical properties were determined using microhardness testing. $\mathrm{Al} / \mathrm{B} 4 \mathrm{C}$ based composites with improved properties were obtained and the role of $\mathrm{Co} / \mathrm{C}$ catalysts was studied.

Keywords: aluminum, boron carbide, composite, SHS process, catalysts.
\end{abstract}

\section{INTRODUCTION}

At present time many compounds have been produced by Self-propagating High-temperature Synthesis (SHS) process [1]. Boron Carbide $\left(\mathrm{B}_{4} \mathrm{C}\right)$ is a hard material $(9.5+$ in Mohs scale) and low specific gravity $\left(2.52 \mathrm{~g} / \mathrm{cm}^{3}\right)$. By using additives (e.g., graphite, cobalt) $\mathrm{B}_{4} \mathrm{C}$ sintered at high temperatures $\left(>2000{ }^{\circ} \mathrm{C}\right)$ can produce microstructures with a high density ( $\sim 98.2 \%$ of theoretical density) [2]. Full density is usually achieved through hot pressing technique however, even in a fully dense form, the sensitivity of boron carbide to brittle fracture remains a major limitation. SHS method has a very wide range of applications [3]. It has been used to produce a wide variety of materials including carbides, catalysts and carriers characterised by high activity and selectivity with high physical and mechanical properties $[1,2]$.

SHS is a relatively novel and simple method for making certain advanced ceramics, composites and intermetallic compounds. This method has received considerable attention as an alternative to the conventional furnace technology. SHS process is based on a system that involves an exothermic combustion. High purity of the product obtained, the possibility to obtain a metastable phase, and the possibility of simultaneous synthesis and densification. Higher purity of the product is a consequence of the high temperatures associated with combustion and the volatile impurities removed as the wave propagates through the sample. Based on the heat released from the reaction of metal powder (fuel) with oxygen (oxidizer) in the presence of other metal oxides hence, after the initial ignition by an external heat source, the reaction is able to regenerate itself while the resulting high temperature sufficient for the synthesis of the desired ceramic product [3,4]. Al, with Boron carbide and the use of a catalyst is to improve the properties of composite materials. This study compared the use of carbon and cobalt as catalysts on $\mathrm{Al}$ composites reinforced by boron carbides. Hardness testing and tracking microstructure by SEM is used to obtain the value of the comparison of the SHS process. In our study the improvement of $\mathrm{B}_{4} \mathrm{C}-\mathrm{Al}$ composite properties was received introducing of Cobalt and metal to initial powder before milling as catalyst.

\section{EXPERIMENTAL DETAILS}

Aluminum powder with average particle size $100 \mu \mathrm{m}$ was received from Aluminum Powder Company Ltd, AlPoCo. Boron carbide had particle size in the range of 17.2 to $74.5 \mu \mathrm{m}$ and with a mean of $17.2 \mu \mathrm{m}$. $\mathrm{Al}$ and $\mathrm{B}_{4} \mathrm{C}$ powder mixture was mechanically activated by attrition mill. The grain size after attrition milling was The SHS process decreased to $\sim 400 \mathrm{~nm}$. The volume fractions used in the composite without catalyst was $50: 50 \%$ and volume fraction for composite with catalyst was $48 \% \mathrm{Al}, 45 \% \mathrm{~B}_{4} \mathrm{C}$, $5 \%$ Co and $2 \% \mathrm{C}$.

Powder composite was milling by attritor for 5 hours. The powder mixtures were densified by vibration and compacted in the steel container. The SHS-process ignition temperature was around $800 \pm 20^{\circ} \mathrm{C}$ and then increased during the SHS process up to $1100 \pm 20^{\circ} \mathrm{C}$ for the used powders content [5]. The heating rate at SHS was higher than attrition mechanical processes. After process the capsules were immediately pressed the heating, then under normal pressure under stress of $150 \mathrm{MPa}$ as shown in Fig. 1.

After SHS, the green samples were removed from the steel container. $\mathrm{HV}_{10}$ hardness is measured. Tabletop Scanning Electron Microscope TM-100 Hitachi was used to obtain the phase distribution. Image-J software was used for quantitative microstructure. Density measurements were performed by Archimedes method using Mettler Toledo ME 204.

\section{RESULTS AND DISCUSSION}

SHS is process that begins at a temperature of 800 to $1200{ }^{\circ} \mathrm{C}$ and resulted to composite $\mathrm{Al} / \mathrm{B}_{4} \mathrm{C}$ forming. SHS

\footnotetext{
* Corresponding author. Tel.: +372-58028403; fax: +372-620 2020.

E-mail address : agus.pramono@ttu.ee (A. Pramono)
} 
with temperatures below $1000{ }^{\circ} \mathrm{C}$ cannot be achieved by sintering technique without pressure, because the contact angle between $\mathrm{Al}$ and $\mathrm{B}_{4} \mathrm{C}$ is not obtained in a short time. Densification hampered caused by chemical reactions occur faster than the reaction of capillarity between $\mathrm{Al}$ with $\mathrm{B}_{4} \mathrm{C}$. The pressing at $150 \mathrm{MPa}$ which is react form result the powder of rearrangement.

However Halverson [1] obtained a low contact angle in a short amount of time because the vapor pressure of aluminum also increases with increasing of temperature. Then the dynamic nature of the contact angle of aluminum on $\mathrm{B}_{4} \mathrm{C}$ will result in mass transfer across the solid-liquid phase interface. Because the system is moving toward a state of chemical equilibrium, $\mathrm{B}_{4} \mathrm{C}$ and $\mathrm{Al}$ react to form composite (see Eq. 1).

$3 \mathrm{~B}_{4} \mathrm{C}+5 \mathrm{Al} \rightarrow \mathrm{AlB}_{12}+\mathrm{Al}_{4} \mathrm{C}_{3}$.

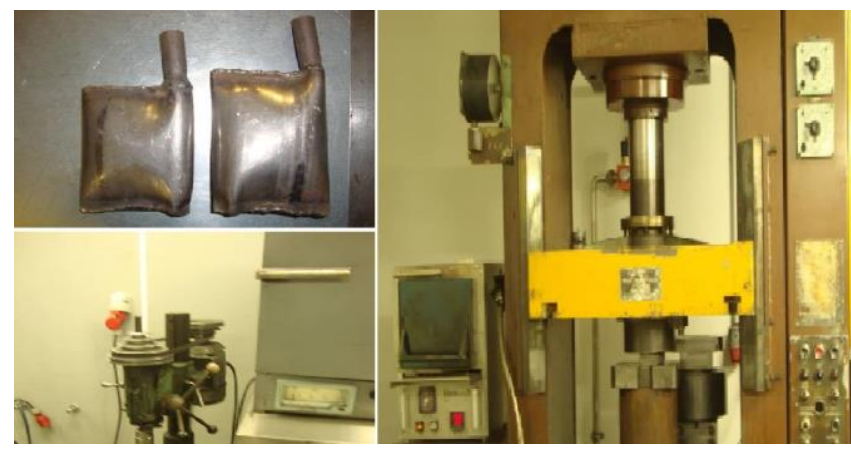

Fig. 1. Stage of SHS Process: preparation of materials, attritor milling and hydraulic pres

Xanthopoulou [2] used Co to increase the activity of catalysts such as the improvent of the properties of composite materials.

Table 1. Mechanical Properties of Composite base Aluminum (Hardness, Density and Porosity measurement)

\begin{tabular}{|c|c|c|c|c|c|c|}
\hline \multirow{2}{*}{ Material } & \multirow{2}{*}{$\mathrm{Vf}(\%)$} & \multirow{2}{*}{ Milling time (h) } & \multirow{2}{*}{\multicolumn{2}{|c|}{ Hardness $\left(\mathrm{HV}_{10}\right)$}} & \multicolumn{2}{|c|}{ Density $\left(\mathrm{g} / \mathrm{cm}^{2}\right)$} \\
\hline & & & & & Measurement & Average \\
\hline $\mathrm{Al} / \mathrm{B}_{4} \mathrm{C}$ & $50: 50$ & 5 & $\begin{array}{l}89.2 \\
88.5 \\
86.3 \\
87.0 \\
86.1 \\
\end{array}$ & $\begin{array}{c}87.4 \\
(\sigma=1.3)\end{array}$ & $\begin{array}{l}2.125 \\
2.128 \\
2.146\end{array}$ & $\begin{array}{c}2.13 \\
(84 \%)\end{array}$ \\
\hline $\begin{array}{c}\mathrm{Al} / \mathrm{B}_{4} \mathrm{C} \\
\text { Catalysts } \\
\mathrm{Co}-\mathrm{C}\end{array}$ & $48: 45: 5: 2$ & 5 & $\begin{array}{l}104.8 \\
102.6 \\
164.7 \\
187.5 \\
179.2\end{array}$ & $\begin{array}{c}147.7 \\
(\sigma=41.0)\end{array}$ & $\begin{array}{l}2.388 \\
2.428 \\
2.431\end{array}$ & $\begin{array}{c}2.42 \\
(82 \%)\end{array}$ \\
\hline
\end{tabular}

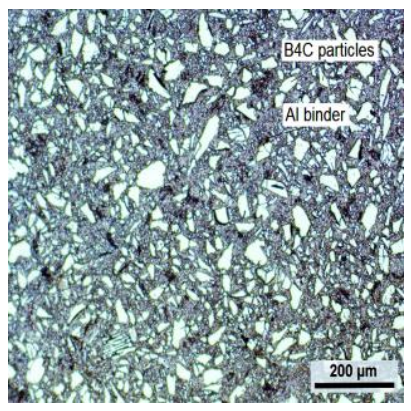

a

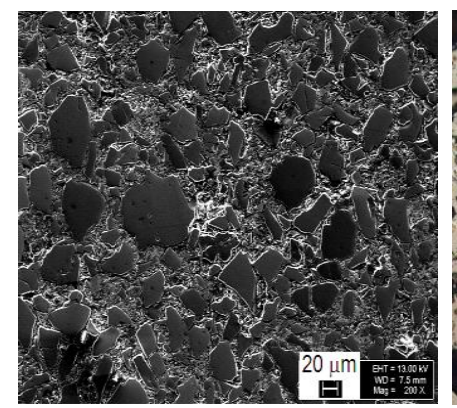

b

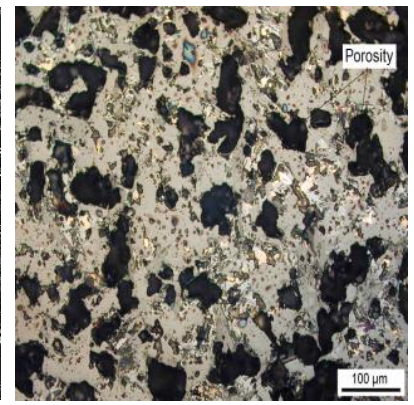

c

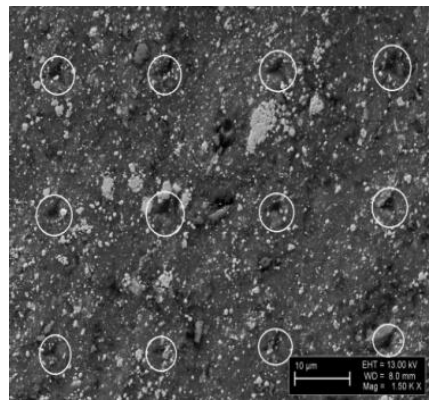

$\mathrm{d}$

Fig. 2. The results of optical and scanning electron microscopy of aluminum-boron carbide based composite: a-SHS processed composite of $\mathrm{Al} / \mathrm{B}_{4} \mathrm{C}$ without catalyst; $\mathrm{b}$ - fine - grained composite $\mathrm{Al} / \mathrm{B}_{4} \mathrm{C}$ with the $\mathrm{Co}-\mathrm{C}$ catalyst; $\mathrm{c}$ - pores in $\mathrm{Al} / \mathrm{B}_{4} \mathrm{C}$ composite as result of new phases forming at presence of $\mathrm{C}$, Co-catalysts; $\mathrm{d}$-ultrafine grained composite of $\mathrm{Al} / \mathrm{B} 4 \mathrm{C}$ with the Co-C catalyst. The micromechanical properties measurements test points are indicated

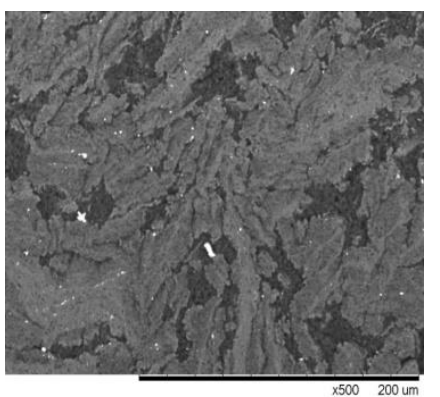

a

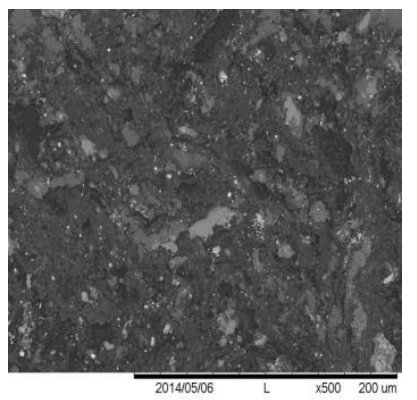

b

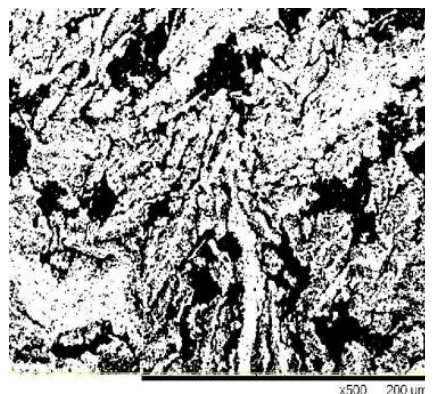

C

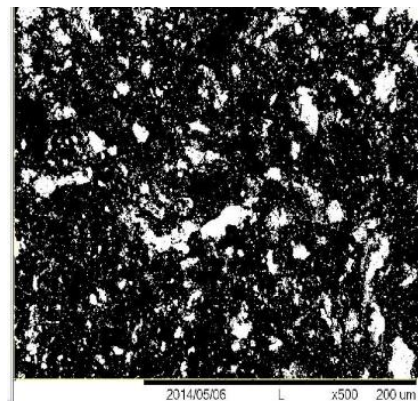

d

Fig. 3. The results of Scanning Electron Microscopy of $\mathrm{Al}$ based composite: $\mathrm{a}$ - composite $\mathrm{Al} / \mathrm{B}_{4} \mathrm{C}$ without catalyst; $\mathrm{b}-$ composite $\mathrm{Al} / \mathrm{B} 4 \mathrm{C}$ with the Co-C catalyst; $\mathrm{c}$ - the results of measurements of grain extracts Image-J software of the composite $\mathrm{Al} / \mathrm{B}_{4} \mathrm{C}$ without catalyst; $\mathrm{d}$ - the results of measurements of grain extracts Image-J software of the composite $\mathrm{Al} / \mathrm{B} 4 \mathrm{C}$ with the Co-C catalyst 
When Co is increased even further in the starting material, the excess Co oxide appears in SHS products that alter the overall function of the dehydrogenation catalyst with the high temperatures [6-8]. Co and $\mathrm{C}$ are used as a catalyst to improve the mechanical properties and the results of the reaction.Cobalt and carbon used as a catalyst to improve the mechanical properties and the results of the reaction shown as in Eq. 2:

$$
\mathrm{Al}+\mathrm{B}_{4} \mathrm{C}+\mathrm{Co}+\mathrm{C} \rightarrow \mathrm{AlB}_{4} \mathrm{C}+2 \mathrm{Co} .
$$

The use of Co-C as the catalyst is able to improve significantly the mechanical properties such as hardness (see Table 1). Without using Co-C catalyst, the hardness of $\mathrm{Al}$ based composite is $87.4 \mathrm{HV}_{10}$ but by using Co-C catalyst the hardness improve significantly to $147.7 \mathrm{HV}_{10}$. The improvement of hardness caused by the improvement of fine grains. The size of the grains become more finer due to the reaction of $\mathrm{Al}$ and $\mathrm{B}_{4} \mathrm{C}$ with the catalysts. If the temperature above $1000{ }^{\circ} \mathrm{C}$ is able to decrease the grain size, the mechanical properties will improve. However, the improvement of mechanical properties will decrease the density of $\mathrm{Al}$ - based composite as a result of increasing the porosity (Fig. 2). The results of composites mechanical properties are listed in Table 1.

The microstructure evolution depending on attrition milling time and processing stage are presented in Fig. 2. By using particle analysis tools in Image $\mathrm{J}$ software, the grain size diameter can be obtained, assumptions the grain area (A) is in the spherical form as shown in equation (3) so the particle diameter $(d)$ can be obtain.

$d=\sqrt{\frac{4 A}{\pi}}$.

Based on the image processing area, average particle calculated by using the analysis particles on image feature, so the image processing can measure the average diameter calculated using equation (2) and the results are shown in Table 2.

Table 2. The results of the average particle size analysis of the samples with 500x magnification. SEM image J software

\begin{tabular}{|c|c|c|c|c|}
\hline Material & $\begin{array}{c}\text { Area of } \\
\text { particle, } \\
\mu \mathrm{m}^{2}\end{array}$ & $\begin{array}{c}\text { Particle } \\
\text { diameter, } \\
\mu \mathrm{m}\end{array}$ & $\begin{array}{c}\text { Average } \\
\text { area of } \\
\text { particle, } \\
\mu \mathrm{m}^{2}\end{array}$ & $\begin{array}{c}\text { Average } \\
\text { particle } \\
\text { diameter, } \\
\mu \mathrm{m}\end{array}$ \\
\hline $\mathrm{Al} / \mathrm{B} 4 \mathrm{C}$ & $\begin{array}{c}47.64 \\
44.27\end{array}$ & $\begin{array}{c}11.68 \\
7.50\end{array}$ & 45.95 & 9.59 \\
\hline $\mathrm{Al} / \mathrm{B} 4 \mathrm{C}$ Co-C & $\begin{array}{c}4.38 \\
3.37\end{array}$ & $\begin{array}{c}2.36 \\
2.07\end{array}$ & 3.87 & 2.21 \\
\hline
\end{tabular}

The grain size of Al-based composite without catalyst measured by Image $\mathbf{J}$ sofware is $9.59 \mu \mathrm{m}$ while using catalyst the grain size becomes finer i.e. $2.21 \mu \mathrm{m}$. Catalyst effected the mechanical properties caused the changing of grain morphology from flake to be a round. Morover, it produces more uniform grain. The catalyst is reacted at temperature from $1000-1200{ }^{\circ} \mathrm{C}$, so the density reduced to $82 \%$ and it is resulted the increasing of porosity about $16.6 \%$.

\section{CONCLUSIONS}

The use of Co-C catalysts in Al-based composite significantly increases the hardness. Initially, the hardness of $\mathrm{Al}$ based composite with $\mathrm{B}_{4} \mathrm{C}$ as reinforced is about $87.4 \mathrm{Hv}_{10}$ and after the addition of Co-C catalysts the hardness become $147.7 \mathrm{Hv}_{10}$, furthermore, the grain size become finer. Without using Co-C catalyst the grain size of Al-based composite with $\mathrm{B}_{4} \mathrm{C}$ is about $9.59 \mu \mathrm{m}$ but after adding $\mathrm{Co}-\mathrm{C}$ catalyst, the grain size become finer i.e. $2.21 \mu \mathrm{m}$.

Morphology of grain size aluminium based composites $\mathrm{B}_{4} \mathrm{C}$ without catalysts is flake and with catalysts $\mathrm{Co}-\mathrm{C}$ the morphology is round. Changes in grain structure in high temperature $\left(\mathrm{Co}-\mathrm{C}\right.$ at $1000-1200{ }^{\circ} \mathrm{C}$ ) reactions lead to a decrease in density so the porosity increases.

\section{Acknowledgments}

This work was supported by the Director General of Higher Education Government of the Republic of Indonesia and Powder metallurgy laboratory Department Material Engineering Tallinn University of Technology Estonia.

\section{REFERENCES}

1. Halverson, D.C. Processing of Boron Carbides-Aluminum Composites Journal of the American Ceramic Society 72 (5) 1989: pp. $775-780$.

http://dx.doi.org/10.1111/j.1151-2916.1989.tb06216.x

2. Xanthopoulou, G. Oxide Catalysts for Pyrolysis of Diesel Fuel Made by Self-propagating High-temperature Synthesis. Part I: Cobalt-Modified Mg-Al Spinel Catalysts The Journal of Applied Catalysis A General (182) 1 999: pp. 285-295.

3. Agrafiotis, C.C., Zaspalis, V.T. Self-propagating Hightemperature Synthesis of MnZn-Ferrites for Inductor Application Journal of Magnetism and Magnetic Material 283 2004: pp. $364-374$.

4. Aminika, B. Investigation of The Pre-Milling Effect on Synthesis of Nanocrystalline TiB2-TiC Composite Prepared by SHS Method. Science Direct Powder Technology 232 2012: pp. $78-86$.

http://dx.doi.org/10.1016/j.powtec.2012.07.058

5. Kommel, L., Traksma, R., Kimmari, E. Influence of Binder Composition and Microhardness on Wear properties of Light Weight Composites Powder Metallurgy Progress 3 (3) 2003, pp. $140-145$.

6. Kommel, L., Kimmari, E. Boron Carbide Based Composites Manufacturing and Recycling Features Material Science (Medžiagotyra 12 (1) 2006: pp. 48-52.

7. Borisova, A.L., Borison, Y.S. Self-propagating High temperature Synthesis for The Deposition of Thermal Sprayed Coating Powder Metallurgy and Ceramic Journal 47 (1-2) 2008: pp. 80-94.

8. Mossino, P. Some Aspects in Self-propagating Hightemperature Synthesis Ceramics International 30 2004: pp. $311-332$. 